\title{
Analysis of Differences in Business Etiquette between China and Africa: The Case of Senegal and Morocco
}

\author{
Kemo Badiane \\ The School of Foreign Languages of Nanfang College-Guangzhou \\ 882, Wenquan Avenue, Conghua District, Guangzhou, Guangdong, China \\ Tel: 86-20-6178-7368Ｅ-mail: didibadiane@gmail.com
}

\begin{abstract}
Huiting Lin
Poly Bay Area Investment and Development Co., Ltd.

1601-1604, Building 1, Suning Plaza, Longhu District, Shantou, Guangdong, China

Tel: 86-20-6178-7368Ｅ-mail: cholenalyn@hotmail.com
\end{abstract}

\begin{abstract}
Hsin-I Lee (Corresponding author)
The School of Foreign Languages, Guilin Tourism University

No.26 Liangfeng Road, Yanshan District, Guilin, Guangxi, China

Tel: 86-135-4344-7675_E-mail: hsini.lee79@gmail.com
\end{abstract}

Received: December 12, 2021

doi:10.5296/jei.v8i1.19315
Accepted: January 21, 2022 Published: February 8, 2022

URL: https://doi.org/10.5296/jei.v8i1.19315

\begin{abstract}
After China's reform and opening-up, trade exchanges between China and Africa have risen sharply. Africa, a continent rich in natural resources, attracts Chinese businessmen and companies. Furthermore, many African countries strongly encourage Chinese firms to invest in. This paper aims at studying the differences in business practices between China and Africa through document analysis, interviews with experienced local businessmen. Focusing on China and two African countries (Senegal \& Morocco), our findings show that the acceptance and respect of cultural differences play a key role in the capacity of Chinese companies and their African counterparts to successfully start business in both countries. Theoretical contribution, managerial implications and limitations are also discussed.
\end{abstract}


Keywords: Different culture, Africa and China, Business etiquette, The countries of ECOWAS, Senegal, Morocco

\section{Introduction}

"Culture is at the beginning and end of any development" (Senghor, 1960). It is therefore the basis of the growth of regions' intellectual potential, citizens' consciousness and open-mindedness edifice. To participate in the political or economic activities of their countries, members should start understanding their local trade practices.

Since its creation, People's Republic of China realized that only a national strong power could suffice to have a place in the world political arena. Economic development is the foundation of one's political high-ranking status on the international scene. China is therefore giving more and more importance to the establishment of mutually beneficial economic, commercial and diplomatic relations with all its partners.

In the development of economic and trade relations between China and Africa, China has made tireless and relentless efforts, including policies updating and continuous improvement. In 2006, China and Africa organized the Beijing Summit of the Forum on China-Africa Cooperation (Chaponnière, 2008). Moreover, they showed the Chinese determination to promote economic and trade development between China and Africa. In terms of content, form and scale, China-Africa economic and trade cooperation thus entered a totally new development phase which is at the same time considerably promising (Bertoncelo \& Bredeloup, 2007). The Chinese President, His Excellency Mister Xi Jinping proposed in 2013 "The Belt and Road Initiative." Presently, more than 69 countries (of them many African countries) and international organizations have already signed agreements with China on "The Belt and Road Initiative" (Aris, 2016). Besides, in 2015, during the opening ceremony of the Forum on China-Africa Cooperation Summit in Johannesburg, in South Africa, the Chinese president Xi Jinping presented "the program for China-Africa Cooperation" and granted \$ 600 billion as financial aid (Ngono, 2017).

In 2012, China signed an economic and trade cooperation framework agreement with the Economic Community of West African States (ECOWAS). Together they discussed new measures, new investment and development methods in the new region. China is showing its support for the integration of West Africa by developing cross-border cooperation in the domain of infrastructures, promoting trade facilitation, deepening investment cooperation, and encouraging the national big companies and financial institutions to follow (Bodomo, 2007; 2010). At the same time, in November 2017, China finished the building of the biggest hydroelectric power station in West Africa, exactly in Supreley in Ivory Coast. Many jobs will be created at the completion of this power station. Up to the present, according to customs statistics in 2017, the transaction amount between China and ECOWAS totaled \$22.3 billion, which means the pace of Chinese companies entering Africa has accelerated.

In this study, we define the etiquette as "a set of rules, social norms, called 'good manners' which govern the behavior to adopt in society" (Le Folcalvez, 1969; Pigozzo, 2011). Therefore, the etiquette participates in good governance and tries to limit people's ways of 
life in the society, it also helps express others respect in accordance with social norms. In the context of our study, the etiquette helps better understand trade practices and cultural differences between countries.

For historical reasons, French is the official language in the bulk of West African countries. To consolidate and strengthen cooperation, the domestic demand of assistants speaking French has increased. They are often sent to Africa to study markets and directly discuss business opportunities with African businessmen/businesswomen for possible trade cooperation in the future.

This article also aims at examining cultural differences between China and Africa. From trade angle, we examine the causes of obstacles on the cross-cultural etiquette in China-African business context and make suggestions so as to overcome cultural constraints. In a way, this article helps facilitate trade negotiation processes at the level of both economic entities.

Today, with the globalization of the economy, a great number of national companies of all sizes are in competition in the new West African markets. How can they be successful? Cultural differences provoke value concept distinctions. From our humble standpoint, it would be very important to fully understand local cultural norms so as to better resort to negotiation techniques during business meetings with clients. This would undoubtedly become a significant asset for a successful cooperation.

As far as the China-Africa economic and trade cooperation is concerned, what are the points of cultural agreement and divergence between China and ECOWAS countries, and China and Morocco? Why are there obstacles and misunderstandings on business culture and practices between China and Africa? How can we avoid or get around these phenomena? Here are some questions we will attempt to answer in this research paper.

Briefly then, the outline of this paper is as follows. Following the introduction, the second chapter presents the literature review introducing African business culture particularly those of Senegal and Morocco. Chapter three discusses the research design methodology, including data collection procedures, interviews and observations. The fourth chapter investigates the causes of business culture between Africa and China and proposing recommendations to Chinese tradesmen and investors to avoid misunderstanding about business culture during China-Africa trade exchanges. As for chapter five, it is drawing the conclusion of the analysis, discussing the limitations of the article and making suggestions for further research.

\section{Literature Review}

\subsection{Business Culture between China and Africa}

Chinese businessmen/businesswomen planning to visit Africa should first understand Africa's political and cultural environment, analyze African cultural characteristics and specificities (Beuret \& Michel, 2008; Michel \& Beuret, 2009; Wagner, 2014). This will help them get adapted without any great difficulty to African culture, political system, methods of work, the continent's different types of reality, but also and particularly know the differences existing between Chinese business culture and customs and African ones. There are many differences 
in business cultures and practices between the two regions based on Hofstede's $(1980,1991)$ cultural dimensions (including high power distance $v s$. low power distance, individualism $v s$. collectivism, high uncertainty avoidance vs. low uncertainty avoidance, achievement vs. nurturing, long-term orientation vs. short-term orientation). For instance, Africa has a short-term orientation, while China has a long-term orientation (Anedo, 2012). Short-term oriented cultures prefer to maximize the present rewards and are comparatively less prone to saving or anticipating long term rewards (McCoy, 1995). Next, these experiences could be used to improve and strengthen economic cooperation between China and Africa (Bodomo, 2010).

When meeting African businessmen/businesswomen, the most common way of greeting is shaking hands with them. This etiquette is identical to China, but for African businessmen/businesswomen, shaking hands with someone is a sign of friendship and goodwill (Roth, 1890); the frequency of handshakes will thus be much more important than in China. Africans have a strong dose of pure love and sensitivity in their hearts. As a matter of fact, we should not scorn or be bored with so frequent handshakes, hugging and kissing with them. This will have an impact on people's feelings and the negotiation atmosphere can also be polluted by this careless mistake. Moreover, the strength of handshakes expresses their sincerity and courtesy. The Chinese believe that excessive efforts would be a display of disrespect or showing off strength. However, African businessmen/businesswomen like strengthening their handshakes to express their respect and sense of welcome and show they consider their friends or sincere partners (Roth, 1890; Morrison, Conaway, \& Avon, 2006). The bulk of them meet addressing one another warm greetings and handshakes followed by "Good morning," "How are you?", "How are your family members?" "God bless you!" and "May we always stay in peace and happiness!" etc. These greetings make people feel warm after listening to them.

African businessmen/businesswomen are always appropriately and elegantly dressed because it is essential to wear the correct attire to business meetings; they know how to harmonize different clothes on different occasions. Thus, Chinese traders should not be less careful with their ways of clothing when it comes to negotiate with them. For Africans, suits are always the expression of one's status and economic power. African businessmen/businesswomen will generously express you their love and admiration, and gratefulness from the bottom of their hearts. When you carefully observe, you will notice they do like using perfume to give off a pleasant smell.

However, time perception for the bulk of Africans during meetings was slightly reduced. This is mainly due to the slowing down of life rhythm and embarrassing traffic in African countries. It is linked neither to the level of employment nor to that of education. Consequently, we should in advance be prepared to start meetings with delay, which could perhaps be the case, but it is better to arrive on scheduled time, because all the African tradesmen wouldn't exactly do so. Several details will obviously show their importance in this collaboration. In the etiquette-based communication, many African countries give much importance to formal rules. Whatever the size of the company (small or big), they can be convenient for an excellent assistant or an exceptional secretary to write a letter, such as the 
sending of a letter of thanks, a letter of congratulations, a letter of greetings, a letter of apologies, a letter of farewells, etc. All of them require the label of these letters (should) be delimited in an appropriate way, in simple, clear and easy terms which are much more easily understood, in modest or respectful language and in formal specifications. As a consequence, in business correspondence and communication with African countries, we should pay attention to format norms and the good use of terms to show our respect for this cooperation between two companies and also respect to African businessmen/businesswomen. In today's global business' context, when meeting companies in Africa in order to start the sooner possible in good conditions a trade negotiation, we should prepare in advance gifts with Chinese characteristics, to better express our sincerity and faith. In African consciousness, helping one another is a question of justice and humanism. It is particularly natural the rich help the poor. If there is a rich person in a family, so s/he will be happy to help all his/her family and friends share his/her wealth.

Before starting business cooperation with African tradesmen, it would be preferable to go to the region and study its creditworthiness and activity. In short, the common characteristic of African tradesmen is their little sense of order but with various goods. Whatever the quantity of the order, African clients prefer receiving complete items as soon as possible. In fact, the best way is working with local businessmen/businesswomen to set up an office or a branch as well as a warehouse in Africa so as to send goods to Africa and facilitate the direct selling either in wholesale or retail to local clients. This would also solve the problem of payment after delivery - the African banks use their corresponding banks in Western countries to issue letters of credit, so people could only choose other payment options. But the situation is sometimes unexpected. For instance, clients are proposed to pay a down payment of 30 percent after the delivery of goods, the remaining 70 percent should be paid later. However, Chinese will sometimes meet clients who would really be unable to pay the remaining purchasing price, which would make them very embarrassing. Though Chinese can transport goods to China, it is too far from Africa, and transportation fees are also very costly. Consequently, before any negotiation with clients, Chinese businessmen/businesswomen must conduct a complete survey on clients' creditworthiness, but also discuss and elaborate a good payment plan depending on clients' current economic situation.

\subsection{Business Etiquette between China and Senegal}

The cultural phenomenon is a complex one (Vigliano, 2011). The African cultural phenomenon mentioned in the preceding chapter is nothing but a general vague phenomenon because there are about 54 countries in Africa, the bulk of which are inhabited by multi-ethnic groups. These groups are very different in terms of cultural norms and practices. Therefore, in a specific country, we must deepen our understanding of its culture and analyze the etiquette in order that we can more easily conduct trade negotiations. Senegal has a stable political situation and good and friendly relations with China. For the last few years, China and Senegal have benefited from a quick development of their bilateral relations and a fruitful cooperation in domains such as economy, trade and human resources management. In 2012, the volume of bilateral trade reached USD $\$ 845$ million, they have increased by 12.9 percent compared to the same period in the previous year, of this China exported $\$ 794$ million and 
imported $\$ 0.5$ billion. According to 2016 statistics, the volume of bilateral trade between China and Senegal quickly increases to 30 percent every year. Relations between China and Senegal have always been oriented to a long-term friendly and cooperative partnership. About 60 percent of the project funds currently coming under "Emerging Senegal Plan" (Sneyd \& Sneyd, 2015; Plan Senegal Emergent (PSE), 2014) that is vigorously implemented by the Senegalese government come from the private sector, which means Senegal will be more open to foreign private investment. To be successful in a good trade cooperation, we must not only conduct a good research and assessment study, but we should also understand in depth the local culture as well as local business practices and ways of doing business; this will be an asset on the trade scene.

Senegal is a hospitable country with plenty of happiness. Not only is it one of the most stable countries in Africa, but its tourist sector also is very developed: "Receiving more than 700,000 tourists every year, Senegal is the first tourist destination in sub-Saharan Africa. Its hotel capacity is estimated to 20,000 beds scattered between 320 hotels." Being the second most powerful economy in French-speaking West Africa, Senegal is known for its Téranga. "Téranga", which is a word borrowed from the Wolof language, refers to its population's hospitality and tolerance. Normally in the region, in order to build personal relations, we must take time to greet, that is more than a simple greeting, and it should always go with a handshake.

Moreover, remember that only the right hand should be used during exchanges in West Africa. In fact, in a business negotiation setting, be relaxed and love people. Do not be extremely impatient. Senegalese businessmen/businesswomen would rather first know their collaborators and vice-versa, eat with them, taste the Senegalese gastronomy and other specialties of the region, present famous local attractions and introduce their family members, because the family and love are very important for the Senegalese. If, during negotiations, we directly avoid this step and jump to the main point of the meeting and immediately start business talks, this will make them sad, and they could think we are not interested in the Senegalese culture, they would even say we are simply there for business, so as to sign contracts and earn a lot of money. In Senegal, the phenomenon and the atmosphere are important. When the Chinese tradesmen talk to Senegalese businessmen/businesswomen, they will give the impression to be at home. An African company is based on the family concept and is an entity in the social service of the community. Work is not a constraint, but it is part and parcel of an adult's life. Thus, in Senegal, covered with love and warmth, human relations are the most fundamental values in the society, do take the necessary time to better understand one another and build a friendly relation in an atmosphere of mutual trust before starting trade negotiations. It is possible to give a good impression during the first meeting with the Senegalese by asking questions and showing your interest in their country and culture, but on the other side rather avoid dealing with points related to religion and sexuality. If you want to know more about local culture and people, generously ask your colleagues or local friends. The Senegalese are generally known as naturally hospitable persons and for them it is a kind of responsibility and pleasure to take care of guests. 
In Senegal, people are very tolerant towards religion and claim their secularity, almost all the persons are believers ( $85 \%$ of Muslims, $10 \%$ of Catholics and $5 \%$ of pagans). People respect one another. It is very common to see a given religious community participate in the religious celebrations of others. There is no inter-religious conflict. As far as work is concerned, it is normal to see someone saying his/her prayers or be missing for a full day because they must attend a naming or wedding ceremony.

The Senegalese have rigorous attitude to work. "Patience and tenacity are essential: time is circular in Senegal. In Africa, time is not that of the clock, but rather that of seasons, that of day and night's succession. Life goes on its own rhythm, without any link with western countries' jerky one. Time is in the instant. If things must happen, they will happen at due time."

People in Senegal are more rigorous in time management. When you and the Senegalese businessmen/businesswomen decide to meet at a given time, they will never miss it whatever the constraints. However, transportation means have an impact on punctuality at work. This is an aspect to take into account. Even if there are particular circumstances which prevent them from arriving on time, they will first inform foreign clients so as to avoid making their friends wait so long. Furthermore, it is very rotten to blame someone's behavior in front of all his/her colleagues during negotiations. We should avoid scolding others when facing other colleagues and employees. Such behavior can be very awkward. It is similar to China. The arrangement of meeting time should also spare participants' rest time. When you first meet tradesmen, try and avoid addressing one another as "Tu". This type of dialogue should only be used after a contact and mutual understanding. "One of the golden rules for Westerners is avoiding any kind of familiarity, particularly in front of an audience or in a group. An African saying goes that familiarity causes scorn."

The Chinese are famous throughout the entire world thanks to their hospitality, and the Senegalese are at the same time talkative and happy. In tune with culture, a little comprehension of the local culture will make negotiations more manageable. During talks, we should make concessions for clients' interests, we should not blindly think of our own interests. If our partners can detect our sincerity, courtesy and seriousness, they will easily and gladly join us to set up cooperation. For foreigners, love and tolerance are the most impressive images of Senegalese people.

\subsection{Business Etiquette between China and Morocco}

As the first economy of North Africa and the current sixth most powerful economy in Africa, Morocco would be the front door connecting Africa and Europe. Not only has the suppression of the visa system for the Chinese going to Morocco provoked tourists' influx, but it has also paved the way for Chinese companies which would like to invest abroad. "To attract Chinese investments, Morocco can be considered as 'capitalist', where the government is not only investing a huge sum of $\$ 2$ billion for Chinese companies, but it also promised Chinese companies to use Morocco as a springboard to enter the European Union and U.S. markets. Moreover, on 21 November 2017, a journalist working for the "Twenty-first Century Economy" interviewed the Moroccan Senior Minister Rakiya Eddarhem, who told Alibaba 
had already had a strategic negotiation with the Moroccan government in July and as a consequence Alibaba's e-commerce activity would soon begin in North Africa. Presently, in "the belt and road" framework, Morocco is actively attracting investments from China and encouraging more Chinese companies to invest there in different sectors of the national economy.

In Morocco, Arabic is the official language, but French retains a major place in Morocco (commerce and economics, culture, sciences and medicine, education, and government). Most of Moroccan businessmen/businesswomen are familiar with French and Spanish. Some educated people also speak English. A part of professionals speak French, Arabic, but don't necessarily understand what is written in. Before travelling to Morocco, you can prepare small gifts for their businessmen/businesswomen; Moroccans like green, red and black colors, but don't like the white one. Pigeon, camel, peacock designs are the most famous ones for Moroccans, whereas hexagonal stars and owl designs are extremely taboo. In Morocco, 13 is a negative figure, however three, five, seven, and forty have a positive meaning. As Chinese nationals, we should prepare souvenirs with Chinese characteristics for Moroccan businessmen, but at the same time avoid their taboos. It is advised to wear at any time conservative-styled costume.

In Morocco, whatever the company type, before meeting employees from a public or private company, you had better make a reservation for an appointment. The negotiation process is serious and formal. When it comes to fix an appointment with Moroccans, please do in advance adequate mental preparations about their possible delays. But they can't be blamed for because they think this is a social style. Before a business meeting, Moroccan businessmen/businesswomen will take the initiative of giving you a business card, so it is better you show your business card printed in both English and French. Since Moroccans like drawing things out, for instance, they will spend much time finishing a required work. This is likely to constrain us to wait for a full day. We should in advance be prepared to this phenomenon and ensure the follow-up in time limits. Given the strict control of foreigners in Morocco, better use (ready) cash during the first transactions with Moroccan businessmen/businesswomen, then choose other types of payment after fixing the credit.

Moroccan businessmen/businesswomen like inviting people to eat at home. However, when invited either at home or at the restaurant to have dinner, most of the meals are extremely delicious. If you are invited by Moroccans at home, they won't generally let their families meet you. After having dinner, and drinking the third cup of mint tea, you should simply stand up and leave. Before entering your Moroccan host's home, the tradition also recommends you take off your shoes.

China and Africa are both warm and hospitable entities, but through discussion on business customs of Africa in general, those of Morocco and Senegal in particular, readers can clearly see there are still big differences between China and Africa. Of course, the respect of cultural differences and the rejection of stereotypes could revitalize trade relations and consolidate diplomatic ties between China and Africa. 


\section{Methodology}

\subsection{Data Collection Procedures}

For the choice of participants, our main targets are individuals who work in business spheres, have a long experience and perfectly master African and Chinese realities in the domain of business. Therefore, we succeeded in mobilizing essentially about ten peoples in each country to participate in our research in order to increase the reliability of our study (Wooding \& Grant, 2003).

Categories of persons we got in touch with are Chinese and African businessmen/ businesswomen living and working in China particularly in Guangzhou (Xiaobei), in Senegal (Dakar), and in Morocco (Casablanca). The reason why they were chosen is these people perfectly and deeply master business culture of the area where they are doing business. For the last few years, China and Africa have much intensified their business relations. Besides, this helped us a lot make the collaboration more sincere and practical with participants who understood the necessity of improving and promoting again this economic and cultural partnership between China and Africa and drawing more their attention on the relevance of our research topic.

\subsection{Interview}

For data collection, we gave priority to the interview for the simple reason that it will be more efficient and effective to listen to our participants so that they can directly tell us their feelings and opinions about the reality they face every day on business culture between China and Africa. For this, we had prepared a certain number of questionnaires we found useful for the understanding of these phenomena. Two items of these questionnaires proposed in our interview are the following:

(1) What are the causes of the rising of obstacles to cultural development in Chinese-Senegalese business talks?

(2) What are the suggestions to better get adapted to business culture in Africa in China-Africa exchanges?

Before the interview, we wrote a letter of introduction in which we clearly explained the purposes of our research and the exclusive use of these data for research aims. In the letter, we promised the participants their personal data will be strictly protected as well as their identities, for no reason, will be revealed to the public or their companies.

Consequently, we also resorted to recording so that we could get the gist of our conversation with participants. For this, we proceeded to the transcription of all the interviews organized with participants to better analyze their results and have at our disposal this information if needs be. This helped us a lot for the interpretation of collected data.

\subsection{Observation}

Observation is a method used to collect information. It is an automatic and selective means of watching and listening to facts or phenomena interaction at the moment they are taking place 
(Kumar, 2005). Thus, the researcher is regarded as an instrument which absorbs all the information sources. There are many situations in which observation can prove (to be) effective to collect information on people's non-verbal behaviors; for instance, when the researcher wants to study a group or an individual's behaviors and personality features. It can also be used in situations where all of the information can't be elucidated by questionnaires.

There are different observation procedures in the domain of research: participating observation and non-participating observation.

Participating Observation: According to Kumar (2005) people talk about participating observation when the researcher participates in the activities of the group exactly as the other members who are observed without their knowing it. For example, someone can stay in a community while trying and deeply studying the cultural aspects of this community without the group knowing it.

Non-participating Observation: Non-participating observation occurs when the researcher is not directly involved in the activities of the group but remains a passive observer watching, observing activities and drawing conclusions from these events for his personal profit (Neuman, 2006).

In this study, we have given priority to the participating method. One of the authors is a citizen of Senegal and the second author, in the framework of her business trip to Dakar (Senegal) and Casablanca (Morocco) got direct contacts with residents of the said countries and the target persons. Through different business meetings, studies were conducted on the field to better grasp business etiquette tips and customs in these countries. The company which the second author works for was in charge of developing its business in these markets. For this, it was important to understand business customs and etiquette to better succeed in this mission. She succeeded in meeting many of their local clients and they were also invited to have dinner at their different clients', which was of a great help to understand cultural differences in business culture, customs and values between China and the above-mentioned countries.

From the three methods: data collection, interview and observation, we can discover problems occurring during China-Africa bilateral trade and cultural talks in a multi-regional perspective. When different cultural labels are understood in various ways, the process of foreign trade cooperation can be the source of misunderstanding and obstacles.

\section{Data Analysis}

\subsection{Analysis of Obstacles on Business Culture between China and Africa}

By culture, one should understand "a set of significations, values and beliefs of collective nature with a certain durability which characterize a group of individuals on a national, ethnic or any other basis and determine their behavior" (Faure \& Rubin, 1993; Faure, 2004). What's more, the most widely accepted definition is "Culture is the total accumulation of beliefs, customs, values, behaviors, institutions and communication patterns that are shared, learned, passed down through the generations in an identifiable group of people" (Hall, 2016, p.230). 
Seemingly, differences of life attitude and the way of thinking are the main reasons of the variety of business culture. This work is thus combining the situation of the Chinese market in Africa and then is also initiating a discussion on its impact on the trade cooperation between China and Africa.

\subsubsection{The Importance of Respect in Interpersonal Relations}

As a Chinese saying goes "At home people rely on their parents, but outside on friends". In China, everybody is aware of the importance of personal relations and believes the more friends they have, the easier it would be for them to solve problems (Garrot, 1995; Gu, Hung, $\&$ Tse, 2008). This also corresponds exactly to African truth. Africans think human relations are essential, even for kinship, "relationship goes beyond the belonging to the same clan or ethnic group, but it has a universal character". In questionnaires, an African student from Ivory Coast studying international trade in Guangzhou, opted to study in China not only for "great business opportunities, but also for meeting more Chinese and making friends with them". This will probably have implications on one's future trade ambitions.

During a business visit to Senegal, we met a trade assistant. During negotiations, we went with him to visit surrounding areas and were presented their spheres of activity as well as products imported from China. When he talked about a sort of glue made in China, he frankly said he hoped we could supply him glue-makers from China. Till the end of the visit, he asked us to find for him four types of Chinese producers. Such a request made us feel ill-at-ease during our first meeting without thus finding a common agreement on our own cooperation.

However, such a situation is not abnormal in Africa. From Descartes to Kant, reason is central in Western philosophy. As far as African philosophy is concerned, without denying the role of reason, rather bases its moral code on interpersonal and community relations (Bujo, 2007). A person is always a human being related to others. Competent persons always need helping those who are in need. However, the Chinese think people should avoid causing distress to those they hardly know. Consequently, the Chinese businessmen, despite the first meeting, would accept demands because it is very difficult for them to learn (how) to turn down even though there are some doubts.

\subsubsection{The Influence of Different Reflection Habits}

The differences in the habits of thinking and action styles can also cause obstacles and even misunderstanding in communication and trade talks. In the questionnaire and interview involving Africans answering to, many participants raised similar questions: Why do the Chinese always work overtime hours without any compensation? Why are Chinese holidays so short? Why don't the Chinese appreciate the weekend, and it seems they still work during weekends? But for the Chinese, work is considered an essential part of their life; people are always enthusiastic and full of energy.

On the contrary, Africans' attitude is the joy of life comes first (Biaya, 1996). For instance, there was a Cameroonian employee working in China who categorically expressed his opinion in the questionnaire. He thought he never wants to work overtime hours, even though 


\section{Macrothink}

these are paid. Moreover, a participant from Morocco who took part in the interview was questioning the idea according to which the Chinese work almost 365 days a year without any leave. One of his friends from Madagascar thanks her grandparents to have migrated from China to Madagascar, so she benefits more from leaves. Obviously, Africans cherish occasions to profit from leave, and will save no time to continue their amusement. Owing to different types of thinking, Chinese negotiators who ignore the African business culture will face an unpleasant situation as we did. Our team travelled to Morocco during the weekend and didn't finally meet all the five partners despite having informed them beforehand. They thought we shouldn't deprive them of their weekend time and then disturb when they are with their families. This is an extremely discourteous act in business etiquette. These examples show African peoples' work and life attitude is very different from the Chinese's one, which must also draw Chinese businessmen/businesswomen's attention (refer to Table 1 for more details). Some Chinese businessmen/businesswomen showed that in Africa, material and financial incentives can also have a negative impact and fail to reach the corresponding results. 
Table 1. Differences in business culture between China and Morocco

\begin{tabular}{|c|c|c|}
\hline Characteristics & Morocco & China \\
\hline Business Mind & $\begin{array}{l}\text { - Better make a reservation for an } \\
\text { appointment. } \\
\text { - They like exchanging business cards } \\
\text { printed both in English and French. }\end{array}$ & $\begin{array}{l}\text { - Possibility of having dinner or } \\
\text { negotiating with partners when they are } \\
\text { free. } \\
\text { - The business card often printed either in } \\
\text { Chinese or in English. }\end{array}$ \\
\hline Time Perception & $\begin{array}{l}\text { - They consider the delay as a social style } \\
\text { without getting the intention of being late. } \\
\text { They are often late at appointment time. } \\
\text { - People inefficiently work and slowly do } \\
\text { the required job. }\end{array}$ & $\begin{array}{l}\text { - Adequately do in advance mental } \\
\text { preparations about their possible delays. } \\
\text { - They prepare in advance to avoid being } \\
\text { late and ensure the follow-up of their work } \\
\text { in time limits. }\end{array}$ \\
\hline Prepared Gifts & $\begin{array}{l}\text { - Moroccans prefer green, red and black } \\
\text { colors, but avoid the white one. } \\
\text { - Pigeon, camel and peacock designs are } \\
\text { the most popular ones. Hexagonal stars } \\
\text { and owl designs are strictly taboo. } \\
\text { - } 13 \text { is a negative figure, whereas } 3,5,7 \\
\text { and } 40 \text { have a positive meaning. }\end{array}$ & $\begin{array}{l}\text { - Presents such as clocks, knives, and } \\
\text { forks have a negative connotation. } \\
\text { - Chinese don't care about the price of } \\
\text { presents and believe presents are signs of } \\
\text { their greetings. However small the present } \\
\text { is, the friendship it expresses is very deep } \\
\text { and honest. }\end{array}$ \\
\hline Dinner label & $\begin{array}{l}\text { - When invited for dinner either at home } \\
\text { or the restaurant, most of the meals are } \\
\text { extremely delicious. They don't let their } \\
\text { families meet clients. } \\
\text { - After drinking the third cup of mint tea, } \\
\text { clients should simply get up and leave. } \\
\text { - Guests should get their shoes off before } \\
\text { entering a house }\end{array}$ & $\begin{array}{l}\text { - In general, formal business dinners will } \\
\text { be organized in a restaurant. } \\
\text { - Chinese pay attention to behaviors at } \\
\text { mealtime. They show their sincerity and } \\
\text { blessing when drinking. } \\
\text { - When eating, people understand one } \\
\text { another's working situation and discuss } \\
\text { social news, but generally they don't } \\
\text { mention questions about personal life. }\end{array}$ \\
\hline
\end{tabular}

Social environment differences widen the gap between ways of thinking between China and Africa as exhibited in Table 2. If we don't try and know African people's way of thinking, this will easily end up with misunderstanding on the business culture and, at the end, won't succeed in winning common interests of both parts. 
Table 2. Differences in Business Etiquette between China and Senegal

\begin{tabular}{|c|c|c|}
\hline Characteristics & Senegal & China \\
\hline Greetings & $\begin{array}{l}\text { - When people meet, they should always } \\
\text { shake hands. }\end{array}$ & $\begin{array}{l}\text { - A single nod is usually enough. } \\
\text { Handshakes are signs of politeness. }\end{array}$ \\
\hline Time Perception & $\begin{array}{l}\text { - They are more rigorous about the time. } \\
\text { - Transportation means have an impact on the } \\
\text { question of punctuality at work } \\
\text { - They first inform foreign clients in order to } \\
\text { avoid making friends wait for long if there } \\
\text { are particular circumstances. }\end{array}$ & $\begin{array}{l}\text { - The Chinese give much importance } \\
\text { to the respect of calendars and time } \\
\text { limits. They appreciate punctuality } \\
\text { and diligence. }\end{array}$ \\
\hline Gestures & $\begin{array}{l}\text { - It is very rotten to blame someone's } \\
\text { behavior in front of all his/her colleagues } \\
\text { during talks. } \\
\text { - When you meet tradesmen for the first } \\
\text { time, try to avoid using "Tu". This type of } \\
\text { dialogue should be done only after a contact } \\
\text { and mutual understanding. }\end{array}$ & $\begin{array}{l}\text { - During meetings, senior officials } \\
\text { will signal inappropriate gestures of } \\
\text { employees and hope everybody avoid } \\
\text { similar errors. }\end{array}$ \\
\hline Religion Perception & $\begin{array}{l}\text { - Most of them are believers. } \\
\text { - They like participating in other believers' } \\
\text { religious celebrations. } \\
\text { - It is normal to see someone saying his/her } \\
\text { prayers or be missing all day long because } \\
\text { they must attend a naming or wedding } \\
\text { ceremony. }\end{array}$ & $\begin{array}{l}\text { - China is a multi-religious country. } \\
\text { People practice Buddhism, Taoism, } \\
\text { Confucianism, etc. } \\
\text { - The Chinese religions have no } \\
\text { influence on Chinese politics and } \\
\text { economy. }\end{array}$ \\
\hline $\begin{array}{l}\text { Business Mind/ } \\
\text { Atmosphere }\end{array}$ & $\begin{array}{l}\text { - They invite clients to taste local } \\
\text { specificities before the beginning of talks, } \\
\text { present famous local attractions and } \\
\text { introduce their family members. } \\
\text { - An African company relies on the family } \\
\text { concept and is an entity at the community } \\
\text { social service. Work is part and parcel of life. }\end{array}$ & $\begin{array}{l}\text { - Not to make people lose time, after } \\
\text { simple greetings during discussions, } \\
\text { they directly deal with the topic. } \\
\text { - Work is part and parcel of life. }\end{array}$ \\
\hline
\end{tabular}

\subsubsection{Africans' Opinion about the Quality of Chinese Products}

The study shows that the intrinsic impression on the Chinese commerce influences African businessmen/businesswomen's judgment about the sincerity of Chinese companies. In questionnaires we handed out to participants, some Africans answering to our questions pointed out that Chinese products were cheap but of low quality. In interviews, others told almost all the products used were made in China, but they were of low quality and they no 
longer dared buying Chinese products. In order to acquire a great part of the market, Chinese companies compete with others by reducing prices and can do nothing but lower the quality of their products. This caused bad purchasing experiences and disrupted the laws of the local market, bringing about failures between both parts.

A Chinese saying goes that, "A seller always peddles their wares". It means that while selling, the seller works hard to give a good image of their own products to get consumers' trust. In fact, in Spain, there is also an example about serious consequences resulting from a blind pursuit of profit by Chinese companies. In 2004, Spain burnt Chinese shoes because Chinese companies excessively search for profits on the field but have rarely recruited local employees. The advantage of their costs put a strong pressure on local companies, which lead to conflicts.

According to Faure (2004), people are at the same time conditioned by reality and their perception of reality. The general development of Chinese companies in the African market will make negative impressions on African businessmen/businesswomen. In their cooperation, African businessmen/businesswomen have inevitably got subjective visions about the knowledge of modern Chinese companies. Erroneous judgments will have an impact on business cooperation between Chinese and African companies and it is difficult to make an agreement.

\subsection{Suggestions to Avoid Cross-cultural Misunderstanding}

suggestions were made to Chinese negotiators and businessmen/businesswomen to avoid misunderstanding and overcome obstacles about business culture and etiquette in China-Africa cooperation. It is a necessity for expatriates to get in the long run African cultural penetration, firmly fix differences in business culture and avoid contentious points. Chinese companies should also adjust their business management styles in Africa and adopt solutions taking into account cultural realities of the country with or in which they are dealing with.

\subsubsection{The Cultural Penetration Strategy}

Before going to Africa, we should first draw up a study to better know the local business culture. Facchini (2008) says "Every society can economically prosper when taking profit from its own cultural tradition and legacy." The understanding and implementation of local culture are the preliminary conditions for economic advantages. Consequently, on the one hand, we must admit and accept the existence of cultural diversity and pay attention to the learning and understanding of language, culture, economics, law, etc. On the other hand, the penetration of African business culture is necessary. If we want to entirely implement African business culture, we should take much time to be trained and informed. Visibly, cross-cultural training is an efficient means for cultural conflicts prevention and resolution. First, Chinese students who study French now learn more about French culture because, the education community could plan to initiate classes for Chinese students on the introduction of French-speaking Africa's cultures. Students can also know African culture in their spare time. Then, for Chinese companies, it is suggested to recruit employees for the training and 
learning of African culture and cultural conflicts management targeting at differences in business culture between China and Africa. This can efficiently help expatriates overcome difficulties resulting from cultural clashes and get adapted to African cultural environment.

\subsubsection{Etiquette Integration and Cultural Escape Strategies}

During negotiations as in any human action, reflection precedes movement. At this level, cultures generate different cognitive approaches (Faure, 2004). It is undoubtedly better to be in the position of Africa's friends who look into local questions, which could give us a clear vision to understand its concern. In a way, when the local business culture is pursued, things will go well more easily. So, this study encourages proceeding to a meeting or cooperation according to local uses. It is generally said "When in Rome, do as the Romans do". For instance, for individuals, we know that in some African regions, it is forbidden to shake hands with a woman for religious considerations. Besides, our African friends think the Chinese are too shy to express themselves. But in China, all this is very normal. In this case, if foreign trade talks require that expatriates follow their partners' culture to be able to react more appropriately, which can help them have a favorable impression and establish a close business relation with their African partners. For Chinese companies, if local cultures were really ignored, this research is proposing to establish the headquarters of the organization in a well-known African country. For instance, we plan to develop our business in Mali, but we knew nothing about. Thus, it would be a good idea to establish a registered office in Senegal in West Africa. This management method beneficial to the cultures of a third country does not only solve specialization problem, but also gains time and energy for their own management. Moreover, this is favorable to the company that can get down to the development of products and sales.

On the other hand, there are big differences between China and African countries in some domains. We should therefore learn to avoid culture points which could probably provoke conflicts. William Hazlitt (1852) says "Prejudice comes from ignorance." Let's get rid of culture ignorance prejudices, and never discriminate against or harm other cultures. For instance, we must respect local religious beliefs and avoid defying ethnic and religious taboos. As a matter of fact, the above-mentioned cultural penetration strategy is a key event, which can help expatriates avoid cultural conflicts.

\subsubsection{Chinese Companies Culture Strategies}

Companies should give a great importance to trade principles and change the company concept which has always given priority to economic advantages. If Chinese companies want to enter the African market, they should elaborate cultural strategies adapted to African countries' business culture.

"This question can no longer be avoided - unless it is a neocolonial activity that does not take into account the black continent humanity, but that only wants to satisfy egoistic interests of countries located in the northern hemisphere" (Bujo, 2007). 
Nowadays, a large number of Chinese companies are set up in the African market. In spite of a fierce competition, they should not give bad impressions to Africans, which can consist of regarding Chinese companies as cherished mercenary raiders.

To become integrated more easily into the local culture, the Chinese company Haier Group Corporation, for instance, preferred recruiting in Africa a great part of its technicians who can take advantage of the business knowledge culture to efficiently run the company. This way of recruiting also reduces the high cost of expatriation of a great number of Chinese employees. The company costs can be reduced in other aspects, rather than reduce the quality of the product. Besides, if African tradesmen suspect the quality of products, Chinese companies could provide samples to test. Or on the premise of their will to cooperate, it is suggested to invite them to visit Chinese manufacturers. Chinese businessmen/businesswomen should combine local business culture in Africa, develop the management strategy on company culture and then express our sincerity to African businessmen/businesswomen.

In this research, there are three main limitations to business etiquette in the economic cooperation between China and Africa. From the Chinese social culture and business point of view, misunderstandings are caused by ignorance in interpersonal relations, the influence of different reflection habits and the impact of intrinsic thinking caused by Chinese trade with Africa. If Chinese companies want to successfully get into the African market and permanently stay there, they should first perfectly understand business culture in Africa. If negotiators ignore the recognition and respect of local cultures, there may be misunderstandings and failures during negotiations and transactions. In addition to, it would be very difficult to make economic profits in the African market. The Chinese companies should avoid mistakes caused, at the level of trade cooperation, by cultural differences.

\section{Discussions and Conclusion}

This paper first introduces differences in cross-cultural etiquette and communication between Africa and China, and then discusses the case of Senegal and Morocco as specific examples. On the basis of the abovementioned studies, this research explains the origins of difficulties in cultural exchanges between China and Africa (Matondo, 2012) from a business point of view. Attitude differences in the domain of life and ways of thinking as well as African peoples' original impression of China are the main reasons which influence trade between China and Africa.

To help Chinese businessmen/businesswomen try hard to avoid misunderstandings, this research is also making some suggestions. First, Chinese businessmen need cultivating cultural consciousness to build profitable relationships (Matondo, 2012). They could get in touch with Africa's sociocultural norms or etiquette and business practices and learn more about Africa at the soonest possible time at university or at companies' level to acquire a good grasp of cross-cultural diversity and African civilization. Second, when Chinese businessmen/businesswomen go to an African country, they have to respect the local culture in order to achieve effective cross-cultural etiquette and global workforce management (Okoro, 2012) and avoid provoking conflicts. Finally, when Chinese companies explore 
markets in Africa, they must be population-centered and insist on the principle of "mutual benefit".

This research study could help government authorities, businessmen/businesswomen, researchers, companies, tourists and other types of Chinese entrepreneurs better understand the differences in business culture between China and Africa and know how to manage a world diversified culture in an inclusive and open way. Furthermore, it will help understand how to avoid misunderstandings in communication by making possible a better understanding in cultural and business domain within both entities.

The findings of this study should be considered in light of its limitations. On the one hand, owing to the lack of experience in trade talks locally conducted and problems of getting primary data, the study can still be deepened at this level using different data collection methodologies to compare results. On the other hand, the study of the African business culture also requires a detailed analysis from the ethnic origin, social environment, economic situation and political development perspective. For that purpose, the findings of this research cannot be generalized to all the African countries as we have focused in this study on only two African countries (Senegal and Morocco). Other studies are expected even necessary to have a more comprehensive approach of the cultural situation in Africa.

We suggest further studies could be initiated to better understand African tradesmen's situation compared to their cultural adaptation in China, language challenges these traders are facing in their daily life or during their business trips to China and vice-versa, the search for consensual solutions which can help consolidate economic and political relations between China and Africa, African consumers' perception of the quality of Chinese products as well as the position of different governments about the improvement of trade relations between China and Africa, etc. We hope this article will draw much attention to the analysis of business practices in different cultural contexts between China and Africa.

\section{References}

Anedo, O. (2012). China-Africa culture differences in business relations. African Journal of Political Science and International Relations, 6(4), 92-96. https://doi.org/10.5897/AJPSIR 11.130

Aris, S. (2016). "One Belt, One Road": La nouvelle route de la soie (p. 3). Center for Security Studies, ETH Zürich.

Bertoncelo, B., \& Bredeloup, S. (2007). The emergence of new African "trading posts" in Hong Kong and Guangzhou. China Perspectives, 1, 94-105. https://doi.org/10.4000/ chinaperspectives. 1363

Beuret, M., \& Michel, S. (2008). La Chinafrique: Pékin à la conquête du continent noir. Paris: Bernard Grasset.

Biaya, T. K. (1996). La culture urbaine dans les arts populaires d'Afrique: Analyse de l'ambiance zairoise. Canadian Journal of African Studies, 30(3), 345-370. https://doi.org/ $10.2307 / 485805$ 
Bodomo, A. (2007). The emergence of African communities in Hong Kong and mainland China (p. 23). Paper for Africa Table, Stanford University African Studies Centre.

Bodomo, A. (2010). The African trading community in Guangzhou: an emerging bridge for Africa-China relations. The China Quarterly, 203, 693-707. https://doi.org/10.1017/ S0305741010000664

Bujo, B. (2007). Culture africaine et développement: Un dialogue nécessaire. Finance \& Bien Commun, 28-29, 40-45. https://doi.org/10.3917/fbc.028.0040

Chaponnière, J. R. (2008). Un demi-siècle de relations Chine-Afrique. Afrique Contemporaine, 4, 35-48. https://doi.org/10.3917/afco.228.0035

Facchini, F. (2008). Culture, diversité culturelle et développement économique. Revue Tiers Monde, 3, 523-554. https://doi.org/10.3917/rtm.195.0523

Faure, G. O. (2004). Approcher la dimension interculturelle en négociation internationale. Revue Française de Gestion, 6(153), 187-199. https://doi.org/10.3166/rfg.153.185-199

Faure, G., \& Rubin, J.Z. (1993). Culture and negotiation: The resolution of water disputes.

Garrott, J. R. (1995). Chinese cultural values: New angles, added insights. International Journal of Intercultural Relations, 19(2), 211-225. https://doi.org/10.1016/0147-1767(95) 99369-4

Gouvernement du Sénégal (Février 2014). Plan Senegal Emergent. Retrieved from https://www.sec.gouv.sn/sites/default/files/Plan\%20Senegal\%20Emergent_0.pdf

Gu, F. F., Hung, K., \& Tse, D. K. (2008). When does guanxi matter? Issues of capitalization and its dark sides. Journal of Marketing, 72(4), 12-28. https://doi.org/10.1509/jmkg.72.4.012

Hall, S. (2016). Cultural studies 1983. Duke University Press. https://doi.org/10.2307/ j.ctv11cw8wg

Hazlitt, W. (1852). The Life of Napoleon Buonaparte (Vol. 1), Cornell University Library.

Hofstede, G. (1980). Culture's Consequences: International Differences in Work Related Values. Newbury Park, CA: Sage.

Hofstede, G. (1991). Cultures and Organizations. New York, NY: McGraw-Hill International. Kumar, R. (2005). Research methodology. New York, NY: Sage Publications Ltd.

Le Folcalvez, F. (1969). ABC du Savoir-Vivre. Paris: Fernand Nathan.

Matondo, J.P.M. (2012). Cross-cultural values comparison between Chinese and Sub-Saharan Africans. International Journal of Business and Social Science, 3(11).

McCoy, F. (1995). Doing Business in South Africa. Black Enterprise.

Michel, Serge, \& Michel Beuret (2009). China Safari: On the Trail of Beijing's Expansion in Africa. New York: Nation Books. 


\section{Macrothink}

Morrison, T., \& Conaway, W. A. (2006). Kiss, bow, or shake hands: the bestselling guide to doing business in more than 60 countries ( 2 nd ed.). Avon, Mass: Adams Media.

Neuman, W. L. (2006). Social research methods: Qualitative and quantitative approaches. Boston: Allyn \& Bacon.

Ngono, L. (2017). La coopération chinoise et le développement en Afrique subsaharienne. Mémoire de Maitrise, Université du Québec à Montréal, Montréal, Canada.

Okoro, E. (2012). Cross-cultural etiquette and communication in global business: Toward a strategic framework for managing corporate expansion. International Journal of Business and Management, 7(16). https://doi.org/10.5539/ijbm.v7n16p130

Pigozzo, F. (2011). "Bagatelles qui caractérisent" L'esprit sociologique du duc de Saint-Simon. Cahiers Saint-Simon, 39(1), 89-100. https://doi.org/10.3406/simon.2011.1491

Roth, H. L. (1890). On salutations. The Journal of the Anthropological Institute of Great Britain and Ireland, 19, 164-181. https://doi.org/10.2307/2842067

Senghor, L. S. (2015). Léopold Sédar Senghor: Africanité-Universalité. Paris, France: L'Harmattan.

Sneyd, A., \& Sneyd, L. Q. (2015). AIMS-Senegal: Assessing the development impact.

Vigliano, L. (2011). Eviter les malentendus interculturels avec des collègues africains. Word Press. Retrieved from https://laurevigliano.wordpress.com/2011/01/22/eviter-les-malentendus -interculturels-avec-des-collegues-africains

Wagner, J. (2014). Chine Afrique, le grand pillage : Rêve chinois, cauchemar africain? Paris, France: Eyrolles.

Wooding, S., \& Grant, J. (2003). Assessing research: the researchers'view. RAND Europe Leiden, Netherlands. Retrieved from https://pdfs.semanticscholar.org/9c27/30e6d1c8520 5c81d4ef832e67eb2feb26cf3.pdf?_ga=2.8495349.1781568699.1574511425-468771065.1574 511425

\section{Copyright Disclaimer}

Copyright for this article is retained by the author(s), with first publication rights granted to the journal.

This is an open-access article distributed under the terms and conditions of the Creative Commons Attribution license (http://creativecommons.org/licenses/by/3.0/). 